\title{
The Differences of Brain Based Learning and Somatic Auditory Visual and Intellectual Based on Brain Gym toward Students' Learning Outcomes and Retention
}

\author{
Fitri Dayanti Aulia ${ }^{1 *}$, A.E. Setiadi' ${ }^{2}$ H.M. Rahayu ${ }^{3}$ \\ 1,2,3 Biology Education, Universitas Muhammadiyah Pontianak, Pontianak, Indonesia \\ e-mail: fltridayantiaulia98@gmail.com ${ }^{1}$, anandita.eka@unmuhpnk.ac.id²,$\underline{\text { hanumunmuhpontianak@gmail.com }{ }^{3}}$
}

\begin{abstract}
This study aims to compare the Brain-Based Learning (BBL) and Somatic Auditory Visual and Intellectual (SAVI) learning models based on brain gym in an effort to improve student learning outcomes and retention. This study was experimental research with a Quasi-Experimental design. The population of this study totaling 62 people, using the BBL learning model for as many as 22 people and using the SAVI learning model for as many as 22 people. Data analysis used a $t$-test with SPSS for windows 22.0. The results showed that the average score of the pretest, posttest, and retest of the $B B L$ class was greater than that of the SAVI class. The t-test analysis obtained a significance value of $0.026<0.05$ for learning outcomes and a significance value of $0.32<0.05$ for student retention. So it can be concluded that there is a significant difference between learning outcomes and retention in the $B B L$ and SAVI learning models which affect learning outcomes and student retention in learning.
\end{abstract}

Keywords: BBL, SAVI, Learning Outcomes, Retention

\section{Introduction}

Biology learning can drive the students in achieving their learning goals. One of the objectives of the learning process is learning outcomes. Each process of assessing learning outcomes provides information to teachers on student progress in the learning process and make it easier for teachers to see the achievement of the learning process (Lubis \& Simatupang, 2014; Widiana et al., 2017). The learning process includes facilities and infrastructure for creating the learning situations were enabling the achievement of learning objectives, one of which is the learning model (Fajriati et al., 2017). The achieved learning goal is influenced by several internal factors in which one of those is retention. Many views refer to the way biology teachers teaching which is currently considered to emphasizing mastering concepts without considering how to dominate a concept in a way that is fun and easy for students to understand so that the material obtained can be absorbed and attached to long-term memory (retention ) of the students (Bahri et al., 2019).

Good retention is the students' need to learn more optimally. This thing can be observed in the students' learning outcomes as well as the assignment of the material that has been studied (Woolfolk, 2010). Retention plays a role in permanent changes in behavior as a result of learning. Student retention can be increased by involving students actively in the learning process (Lubis \& Simatupang, 2014; Trilipi et al., 2019). Therefore, good retention power will make students achieve good learning outcomes. However, the facts in the real learning situation show that not all students have good retention power. Ideal education is an education which the students who are learning by maximizing the abilities students have.

Based on preliminary observations carried out at SMP Negeri 2 Rasau Jaya, students' memory of the science obtained learning material is currently low. This was seen when the science teacher asked students some questions during learning about what has been previously learned in the last meeting. Less than $50 \%$ of students could answer these questions, but most students were not able to recall and answered the questions related to the material. The large number of biology materials that require real understanding made

\footnotetext{
${ }^{*}$ Corresponding author.

Received 13 February 2020; Accepted 16 September 2020; Available online 01 March 2021

(C) 2020 JPI. All Rights Reserved
} 
students remember the concepts to answer the questions they are learning (Fatmawati et al., 2019). In every learning process, retention plays an important role as a result of what has been learned to improve student learning outcomes (Nurwidodo, 2016).

Memory is closely related to the ability of a person's brain. The working mechanism of the brain is a major part of memory reception and storage. The more often the brain is trained, the memory or retention will increase (Nuryana \& Purwanto, 2010). The working mechanism of the brain can be stimulated through light movements that involve body movements such as brain exercise or what is called a brain gym. Light movements in the brain gym involve more hand movements (Pramesti et al., 2018). The level of concentration in children before and after being given the brain gym intervention has a significant difference seen from the results of the average student concentration level test (Handayani \& Corebima, 2017). The same research was also carried out by Nuryana and Purwanto which resulted that the brain gym has high effectiveness in increasing student concentration in terms of student learning outcomes (Nuryana \& Purwanto, 2010). The brain gym in this study uses light movements that are relatively easy to follow. Hand and foot movements in the brain gym can also be used to convey material on the system of motion, especially on the concept of joints and the names of bones.

The implementation of a brain gym in learning requires an appropriate learning model. Learning models that involve brain activity can affect improving student learning outcomes. Based on research conducted by Fajriati student learning outcomes increased by providing the Brain-Based Learning method based on a brain gym (Fajriati et al., 2017). Not only that, methods that involve brain and body activity can also be used in the Somatic Auditory-Visual and Intellectual (SAVI) model. The SAVI learning model involves more bodily activities. SAVI makes students more active so that learning is more meaningful (Wijayanti et al., 2013). The approach to the SAVI learning model based on the brain gym carried out by Fiah and Rinaldy (2015) resulted that there is a significant effect on cognitive learning outcomes in science learning seen from the increase in students' pretest and post-test scores.

The implementation of this model involves a brain gym (brain gym) to help the brain work better. This study uses a learning model based on thinking and sensory tools, namely Somatic Auditory-Visual and Intellectual or SAVI based on brain exercise to increase physical activity and student brains in a learning process. Based on the description above, this study aims to compare the two learning models to see the differences in learning outcomes and retention of students who use the brain gym-based BBL learning model with the brain gym-based SAVI on the movement system material.

\section{Method}

The current study used Quasi-Experimental with Nonequivalent Control Group Design. The population in this study were 62 students of class VIII SMP Negeri 2 Rasau Jaya in the academic year $2019 / 2020$. Homogeneity test results showed the population is in a homogeneous state. Sampling was carried out by simple random sampling. The sampling was randomly selecting class VIII A as the experimental class 1, using the brain gym-based BBL model and class VIII B as the experimental class 2, using the brain gym-based SAVI model. The data collection used 15 questions of cognitive test instrument for learning outcomes and 20 questions of student retention test. The test instrument was in the form of multiple-choice questions. Data analysis consisted of the analysis of prerequisite tests and hypothesis tests. The analysis prerequisite test included the average value (mean), normality test, and homogeneity test, as well as hypothesis testing using the t-test. 


\section{Result and Discussion}

\section{Results}

Average Value of Learning Outcomes and Student Retention

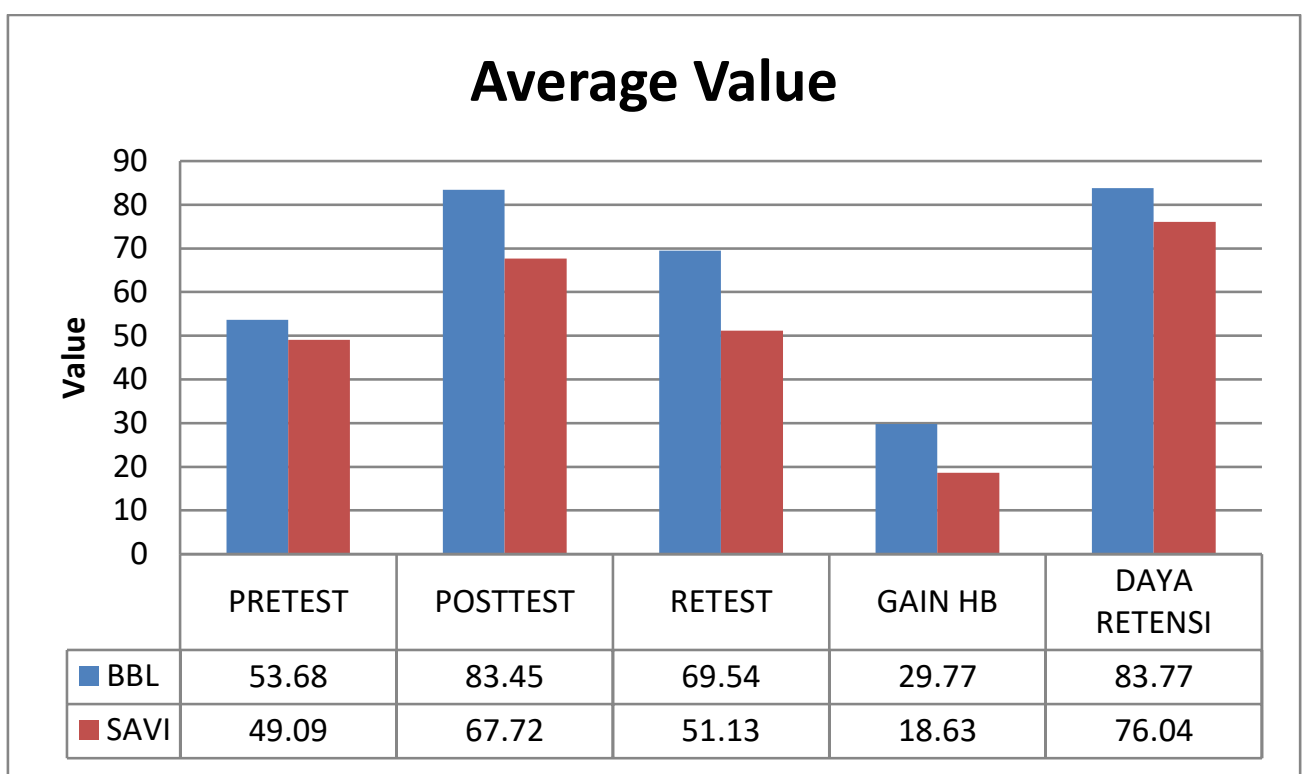

Figure 1. Recapitulation of the Average Value of Experiment Class 1 and Experiments 2

Based on Figure 1, the average value of the pretest, post-test, retest value, learning outcomes, and retention power in the two experimental classes gained different results. It can be seen that there is a decreasing value in the average retest value compared to the post-test value. This is due to the student's forgetfulness because the retest was held 2 weeks after the post-test was given (Hasanah et al., 2017). Forgetting is a common occurrence because of human limitations in remembering (Jayalakshmi \& Annakodi, 2013). Thus, doing a retest in a period where students have received some new material while in learning, the new material can be a factor that affects recall of material that has been stored in memory (Hasanah et al., 2017). The retention power value is the value obtained from the results of the repetition of the test for 2 weeks after the post-test is carried out (Fausan \& Pujiastuti, 2017). This value is generated from the retest value reduced by the post-test value (Trilipi et al., 2019). The mean value of pretest, post-test, retest, gain, and retention power in the experimental class of BBL was greater than that of the experimental class SAVI. The average pretest score for the BBL class was 53.68, while the SAVI class was only 49.09. The average post-test score in the BBL class reached 83.45 while in the SAVI class only got an average score of 67.72 and on the retest value the BBL class got an average score of 69.54 while in the SAVI class it was 51.13. Measuring the Difference in Learning Outcomes.

The measurement of differences in learning outcomes using gain value data through several stages of analysis. The first stage was the normality test using the Shapiro Wilk analysis with the following results (Table 1):

Table 1. Normality Test of Learning Outcomes

\begin{tabular}{llll}
\hline \multicolumn{1}{c}{ Class } & \multicolumn{2}{c}{ Shapiro Wilk } \\
\hline & Statistic & Df & Sig \\
\hline BBL & 9940 & 22 &, 197 \\
SAVI &, 930 & 22 &, 125 \\
\hline
\end{tabular}

The normality test result of student learning outcomes for the BBL class had a significance value of 0.197 and the SAVI class had a significance value of 0.125 . The 
significant number in the BBL class is greater than $0.05(0.97>0.05)$ and the significance level in the SAVI class is greater than $0.05(0.125>0.05)$. Both classes have normally distributed data. Further data analysis was carried out by the homogeneity test. Homogeneity test data can be seen in the following table (Table 2):

Table 2. Learning Outcomes Homogeneity Test

\begin{tabular}{llll}
\hline Statistic & $\boldsymbol{d f 1}$ & $\boldsymbol{d f 2}$ & Sig. \\
\hline, 001 & 1 & 42 &, 982 \\
\hline
\end{tabular}

Based on the homogeneity test, the significance coefficient value is greater than the significance level $(0.982>0.05)$ so that it can be concluded that all data are homogeneous. The next step of analysis is to test the hypothesis with the t-test with the following results (Table 3):

Table 3. Learning Outcomes T-test Table

\begin{tabular}{|c|c|c|c|c|c|c|}
\hline CLASS & $\mathbf{N}$ & & Mean & \multicolumn{2}{|c|}{ Std. Deviation } & Std. Error Mean \\
\hline $\mathrm{BBL}$ & 22 & & 29,7727 & \multicolumn{2}{|c|}{15,14040} & 3,22794 \\
\hline SAVI & 22 & & 18,6364 & \multicolumn{2}{|c|}{16,84254} & 3,59084 \\
\hline $\begin{array}{l}\text { Learning } \\
\text { Outcomes }\end{array}$ & $f$ & sig & $t$ & $d f$ & $\begin{array}{l}\text { Sig (2- } \\
\text { tailed) }\end{array}$ & Mean Difference \\
\hline Equal & & & & & & \\
\hline variances & & & 2,306 & 42 & ,026 & 11,13636 \\
\hline $\begin{array}{l}\text { assumed } \\
\text { Equal }\end{array}$ & ,001 & ,982 & & & & \\
\hline $\begin{array}{l}\text { variances not } \\
\text { essumed }\end{array}$ & & & 2,306 & 41,532 & ,026 & 11,13636 \\
\hline
\end{tabular}

The value of Sig. Levene's Test for Equality of Variances is $0,982>0,05$ it can be interpreted that the data variance of the two classes is homogeneous or the same. So that the interpretation of the results table is guided by the value of Equal Variances Assumed. Based on the table above, it is known that the value Sig. (2-tailed) is 0,026 $<0,05$ then based on decision making in the independent sample t-test it can be concluded that $\mathrm{H}_{\mathrm{o}}$ is rejected and $\mathrm{H}_{\mathrm{a}}$ is accepted. Thus that there are differences in learning outcomes for the BBL and SAVI classes.

\section{Retention Power Measurement}

After obtaining the average value of retention power, analysis testing was carried out through several stages. The first stage was the normality test using the Shapiro Wilk analysis. The results of the normality test are presented in the following data (Table 4):

Table 4. Normality Test Retention Power

\begin{tabular}{llll}
\hline \multirow{2}{*}{ Class } & \multicolumn{3}{c}{ Shapiro Wilk } \\
\cline { 2 - 4 } & Statistic & Df & Sig \\
\hline BBL &, 931 & 22 &, 129 \\
SAVI &, 874 & 22 &, 069 \\
\hline
\end{tabular}

Based on table 4.5, the normality test results obtained from the retention power of the BBL class have a significant number of 0.129 and the SAVI class has a significant number of 0.069 . The significance level in the BBL and SAVI classes is greater than the significance level (0.05). Therefore, both classes have normal data, then it will be followed by a variance 
homogeneity test to see whether the two data are homogeneous or not. The homogeneity test data is presented in table 5.

Table 5. Retention Power of Homogeneity Test

\begin{tabular}{llll}
\hline Statistic & df1 & df2 & Sig. \\
\hline 1,114 & 1 & 42 &, 713 \\
\hline
\end{tabular}

Based on the homogeneity test on the retention power for the BBL and SAVI classes, the significance value obtained is greater than the significance level $(0.713>$ 0.05). So it can be concluded that the retention power between the BBL and SAVI classes is homogeneous. After it was known that the data is normal and homogeneous, then a hypothesis test would be carried out, namely the t-test.

Table 6. Retention Power of T-test Table

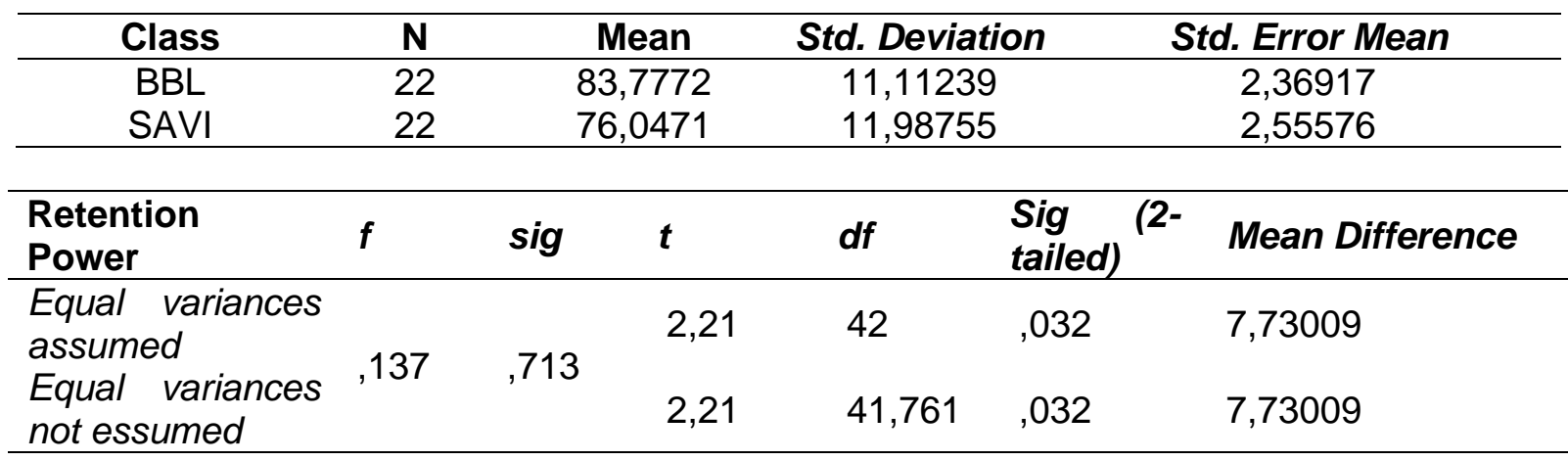

The sig value of Levene's Test for Equality of Variances is $0.713>0.05$, it means that the data variance of the two classes is homogeneous or the same. So that the interpretation of the results table is guided by the value of the Equal Variances Assumed. It is known that Sig. (2-tailed) value is $0.032<0.05$, so based on decision making in the independent sample $\mathrm{t}$-test it can be concluded that $\mathrm{Ha}$ is accepted and $\mathrm{Ho}$ is rejected. Thus, there is a difference in retention power for the BBL and SAVI classes.

\section{Discussion \\ Learning Outcomes}

Learning is the result of what is learned from a learning objective which can be said as a wanted learning outcome (Kawuri et al., 2019). Learning outcomes can be in the form of behavior changes that occur after participating in the teaching and learning process according to educational goals. Learning outcomes can be influenced by the application of the learning model given during the learning process. The problem in this present study is seeing how the differences in learning outcomes using two different brain gym-based learning models, namely Brain-Based Learning (BBL) and Somatic Auditory-Visual and Intellectual (SAVI). Experiment class 1 used a brain gym-based BBL model wherein the preparation stage students prepared to receive learning, paid attention to perceptions and indicators as well as learning objectives, and responded to teacher questions. However, before learning begins, the teacher gave students practice questions as a pretest to measure students' initial abilities. After that, the teacher provided an explanation of the movement system material to students. Students were given a presentation of the motion system material, and gave worksheets. To stimulate the students's brains, the teacher provided brain exercise exercises that each student must do students' the brain twice. After learning ended, the teacher provided feedback to students and provided practice questions in the form of post-test questions to measure students' abilities after being explained the material and brain exercise exercises. 
Based on the research that has been carried out in the experimental class 1 with the brain gym-based BBL model, the average gain value is 29.77 . While the experimental class 2 with the brain gym-based SAVI model obtained an average gain value of 18.63. These results indicate that the provision of the BBL learning model has a higher average value than the SAVI learning model. So it can be said that the provision of the BBL model has more effect on learning outcomes.

The implementation of the brain gym-based learning model that has been carried out has an influence on students' understanding of the material given. This can be observed from the post-test results that achieved mastery (86\%) for the BBL learning model and (54\%) for the SAVI learning model. This proves that the brain gym that is carried out can refresh the physical and mind of students after undergoing the learning process which results in fatigue and tension in the brain which results in a decrease in student learning concentration (Handayani \& Corebima, 2017). Brain gym is a brain stretch that is done by stimulating brain waves through light movements with games such as hand and leg exercises, which requires a high enough concentration in its implementation (Pramesti et al., 2018). Learning models that involve brain activity can affect improving student learning outcomes. Student learning outcomes increased by providing a brain gym-based Brain-Based Learning model (Fajriati et al., 2017). Brain-Based Learning or brain-based learning is where brain function and its role in learning are used (Faidi, 2013).

The Brain-Based Learning model considers how the brain works while retrieving, processing, and interpreting information that has been absorbed. This can be seen from the results of the post-test. This learning model can facilitate brain performance so that learning can be done naturally (Widiana et al., 2017). Brain-based learning helps to optimize the work of the brain by creating learning environments that challenge students' thinking skills, create pleasant learning environments, and create active and meaningful learning situations for students. One of the important points in BBL-based learning is meaningful learning for students (Gozuyesil \& Dikici, 2014). The learning process that involves the activation process of students makes learning fun. This happens because students will play a role in it and can develop their potential. BBL is a learning model related to how the brain works naturally in learning (Kartikaningtyas et al., 2017). This supports the provision of a brain exercise activity that can increase the brain's performance at work. The use of the BBL model is also felt (Prastuti et al., 2019) which can improve completeness and learning activities of class XI MIA 1 SMA Negeri Boyolali by proving that the test results of the cycle I and cycle II have increased according to the predetermined success indicators. This also happens when the research was carried out that the post-test results (tests after learning) have increased. Brain-based learning shows a more optimal level of understanding of learning and can show high creative thinking skills compared to conventional learning models (Widiana et al., 2017).

In the learning process, this model provides opportunities for students to recall some of the materials contained in brain exercise movements. This study is in line with previous research who says that in the BBL model, the views and goals of students' body movements rely on cognitive theory (Handayani \& Corebima, 2017). This supports the cognitive enhancement of student learning outcomes in the research that has been done. Based on the learning syntax according to (Jensen, 2008), relaxation can be included in the incubation and verification stages. At the incubation stage, students are given brain exercises in a standing position. Meanwhile, at the verification stage or re-checking students do brain exercises in a sitting position. This can support that the BBL model has a higher yield than the SAVI model.

The implementation of the SAVI model based on brain exercise also gave quite good results, but the completeness rate of the post-test score of this model was not higher than the completeness in the BBL model. This model helps students in practicing body movements due to the simulation stages in learning. The real simulation stages in the SAVI learning model are given brain exercises which can help students to apply the theory that has been given. Brain-based learning helps students optimize their brains to think and seek knowledge through an active learning process so that student learning is more meaningful 
(Lidiastuti et al., 2019). It can also help create a relaxed learning environment to create an optimal learning environment emotionally and socially (Salem, 2017).

The results of this study are in line with Mustiada's (2014) research which states that there is a positive influence on brain-based learning models on science learning outcomes. The application of brain-based learning can improve the mathematics problem-solving abilities of class V students (Nyoman, 2020). This is also in line with what (Jensen, 2008) stated, that the Brain-Based Learning method offers a concept to create effort-oriented learning. empowerment of students' brain potential. In applying the brain-based learning approach, several things must be considered because it will greatly affect the learning process, namely the environment, movement and sports, music, games, mind maps, and the teacher's appearance.

\section{Retention Power}

Retention is one of the phases that emphasizes the storage of newly acquired information and the transfer of information from short term memory to long term memory. Retention has several functions for the teacher, namely being able to determine the quality of learning and improve the learning process, provide learning according to students' ability to remember the material, and can maximize the learning time interval. The importance of using multiple senses is to improve learning outcomes in the cognitive realm and maintaining student retention data, science learning can facilitate this. The BBL and SAVI learning model is an approach that involves all five senses.

Retention measurements that have been carried out by giving retest questions at certain time intervals, namely 2 weeks after the post-test administration. This is supported by Herlanti's opinion which states that the comprehension test (post-test) is carried out after the learning is complete, while the retest is carried out after two weeks of learning stops (Herlanti et al., 2007). This research has also been conducted by Juniarsih which states that low retention of learning can be seen from the results of students' answers to the evaluation questions given by the teacher a week to two weeks after the material is delivered (Juniarsih et al., 2015). About $68.75 \%$ of students still have not re-described the lessons that have been delivered and the scores have not reached the KKM, this shows that students have not been able to retain the information they have obtained. Student retention data can be calculated from the comparison of retest scores with the first post-test (Hasanah et al., 2017).

The analysis result of students' retention values showed that there was a difference between the results of the retention rate of the brain gym-based BBL class and the brain gym-based SAVI class. This is proven by the acquisition of t-test results which indicate that the significance value is smaller than the significance level $(0.032<0.05)$ because in the $\mathrm{BBL}$ and SAVI classes there are differences in the provision of a brain gym in-class teaching. Retest questions were given two weeks after the learning process was completed. Retention tests are related to the learning process and outcomes because they are carried out after the learning process and learning outcomes are obtained. The length of time is due to long term memory when maintaining information ranges from 30 seconds and above.

Based on the retention value of students in the BBL class and SAVI class, the average percentage of student retention power with the BBL model is 83.77 and the average retention power in the SAVI class is 76.04. This shows that the retention power in the BBL class is higher than the SAVI class. This difference in retention is due to the teaching and learning process in the BBL class based on Jensen's syntax (2008) which is given 2 repetitions in the brain gym, namely the incubation stage entering memory and the verification and confidence checking stage. The SAVI class only does one brain gym movement, namely in a real simulation at the training stage (somatic). To maintain the information that has been obtained, it can be helped by providing repetition. Repetition is an effort that can help increase retention, especially to maintain information in long-term memory (Juniarsih et al., 2015). Repetition serves to re-coding strategies for more reinforcement and improvement; this allows long-term memory to be stronger (Sprenger, 2011). Each student has different retention; however, retention can be improved with presentation techniques. 
Giving a brain gym also affects student retention. Based on research conducted by Saleh \& Mazlan (2019) who uses the brain gym method, it is said that there is a focus on optimal brain function, promoting and improving students' thinking skills and creating a relaxed and enjoyable learning environment. It can be a significant trigger for students to understand better the learning material conceptually and optimally in the subject. This makes it easier for students to recall the material because this video can also remind students of the material that has been delivered. The collaboration of the BBL learning model with a brain gym can also provide a relaxed atmosphere in learning. Brain-Based Learning model contains three important rights in learning, namely, learning that makes students related to the material being studied, learning that eliminates the fear of students by creating a relaxed atmosphere and making students actively process (Jayalakshmi \& Annakodi, 2013). Meaningful learning of students occurs when what is learned and emphasizes associating experiences, phenomena, and new facts will make students more understand and remember the material being studied. Not only are seen but the video movement is also followed by students so that the information stored in memory the short term will be easily transferred to the long term memory and lead to better student retention. Each student has different retention, but student retention can be improved with presentation techniques.

\section{Conclusions and Suggestions}

Based on the data analysis and discussion, it can be concluded that there is a difference between learning outcomes and student retention using the Brain-Based Learning (BBL) learner model with Somatic Auditory-Visual and Intellectual (SAVI). This can be seen from the gained value in learning outcomes and the value of the retention power of the students in each experimental class can also be seen from the significance of the results of the data analysis that has been carried out. The learning model that has a major influence on student learning outcomes and retention is the brain gym-based BBL learning model. This learning model can be used as a learning model that can improve student retention results so that learning outcomes can also improve properly.

\section{References}

Bahri, A., Idrus, I. S., \& Samsidi, N. H. (2019). Retensi Kognitif Biologi dan Sikap IImiah Siswa Berkemampuan Akademik Berbeda pada Strategi PBLRQA dipadu Jurnal Belajar. Sainsmat: Jurnal IImiah IImu Pengetahuan Alam, 8(1), 86. https://doi.org/10.35580/sainsmat81101912019.

Faidi. (2013). Tutorial Mengajar untuk Melejitkan Otak Kanan dan Otak Kiri Anak. Diva Press.

Fajriati, I. S., Safei, \& Saprin. (2017). Pengaruh Penerapan Metode Pembelajaran Brain Based Learning Berbantuan Brain Gym Terhadap Hasil Belajar Peserta Didik. Jurnal Biotek, $5(1)$, 110. http://journal.uinalauddin.ac.id/index.php/biotek/article/view/3442/3237.

Fatmawati, F., Sukariasih, L., Fayanto, S., \& Retnawati, H. (2019). Investigating the Effectiveness of Inquiry Learning and Direct Learning Models Toward Physics Learning. Advances in Social Science, Education and Humanities Research. https://doi.org/https://doi.org/10.2991/iconprocs-19.2019.54.

Fausan, M. M., \& Pujiastuti, I. P. (2017). The Effect of CTL Approach Based on NHT Learning Model toward Students' motivation, Science Achievement, and Retention. $\begin{array}{llll}\text { Jurnal Pendidikan Biologi Indonesia, } & 33 .\end{array}$ https://doi.org/10.22219/jpbi.v3i2.4278.

Gozuyesil, E., \& Dikici, A. (2014). The Effect of Brain Based Learning on Academic Achievement: A Meta-Analytical Study. Educational Sciences: Theory and Practice, 14(2), 642-648. https://eric.ed.gov/?id=EJ1038792.

Handayani, B. S., \& Corebima, A. D. (2017). Model brain-based learning (BB) and whole 
brain teaching (WBT) in learning. International Journal of Science and Applied Science: Conference Series, 1(2), 153. https://doi.org/10.20961/ijsascs.v1i2.5142.

Hasanah, N. N., Supeno., \& Wahyuni, S. (2017). Kekuatan Retensi Siswa SMA Kelas X Dalam Pembelajaran Fisika Pada Pokok Bahasan Momentum dan Impuls Menggunakan LKS Berbasis Mind Mapping. Jurnal Pembelajaran Dan Pendidikan Sains, 2(1), 25-32. https://jurnal.unej.ac.id/index.php/jpps/article/view/6410.

Herlanti, Y., Rustaman, N. Y., \& Setiawan, W. (2007). Kontribusi wacana multimedia terhadap pemahaman dan retensi siswa. Jurnal Pendidikan IPA: Metamorfosa, 2(1), 29-38.

Jayalakshmi, R., \& Annakodi, R. (2013). Brain Based Learning Strategies. International Journal of Innovative Research and Studies, 2(5). https://www.researchgate.net/publication/324704225_Brain_Based_Learning_Strateg ies.

Jensen, E. (2008). Brain Based Learning. Pustaka Pelajar.

Juniarsih, Q. A., Chamisijatin, L., \& Hindun, I. (2015). Peningkatan Retensi Belajar Materi Klasifikasi Makhluk Hidup Melalui Penerapan Discovery Learning dan Team Games Tournament pada Siswa Kelas VII-G SMP Negeri 18 Malang. Prosiding Seminar Nasional Pendidikan Biologi, 157-167. http://eprints.umm.ac.id/id/eprint/20853.

Kartikaningtyas, V., Kusmayadi, T. A., \& Riyadi. (2017). Contextual Approach with Guided Discovery Learning and Brain Based Learning in Geometry Learning. Journal of Physics: Conference Series, 895(1). https://doi.org/10.1088/1742-6596/895/1/012024.

Kawuri, M. Y. R. T., Ishafit, I., \& Fayanto, S. (2019). Efforts to improve the learning activity and learning outcomes of physics students with using a problem-based learning model. IJIS Edu: Indonesian Journal of Integrated Science Education, 1(2), 105-114. https://doi.org/http://dx.doi.org/10.29300/ijisedu.v1i2.1957.

Lidiastuti, A. L., Prihatin, J., \& Iqbal, M. (2019). The development of EXAIR (example auditory thinking repetition) learning model based on BBL (Brain-Based Learning) and its effect on problem solving capability on secondary school in coastal area. IOP Conference Series: Earth and Environmental Science, 243(1). https://doi.org/10.1088/1755-1315/243/1/012094.

Lubis, N. F., \& Simatupang, Z. (2014). Peningkatan Daya Retensi Siswa Terhadap KonsepKonsep Biologi Melalui Pemanfaatan Media Adobe Flash pada Model Pembelajaran Langsung. Prosiding SEMNAS Biologi Dan Pembelajarannya, 654-664. http://digilib.unimed.ac.id/id/eprint/4831.

Nurwidodo, W. R. S. (2016). Developing Learning Model ASSURE Based Competence for Improve Retention and Material Mastery Training Participants. Proceedings of International Research Clinic \& Scientific Publications of Educational Technology, 1(2), 396-423. https://journal.unesa.ac.id/index.php/jtp/article/view/1167.

Nuryana, A., \& Purwanto, S. (2010). Efektivitas brain gym dalam meningkatkan konsentrasi belajar pada anak. Indigenous: Jurnal Ilmiah Psikologi, 12(1), 88-99. https://doi.org/10.23917/indigenous.v12i1.1558.

Nyoman, D. (2020). Penerapan Model Pembelajaran Berbasis Masalah Untuk Meningkatkan Kemampuan Pemecahan Masalah Matematis Siswa Kelas V Sekolah Dasar. Jurnal Pendidikan Guru Sekolah Dasar, 4(3), 390-399. https://doi.org/10.17509/jpgsd.v4i3.22948.

Pramesti, T. A., Sastrawan, K. B., \& Wardhana, Z. F. (2018). Pengaruh Brain Gym Terhadap Tingkat Konsentrasi Belajar Pada Anak Sekolah di SD Negeri 1 Tonja Denpasar. Bali Health Journal, 2(1), 12-22. http://ejournal.unbi.ac.id/index.php/BHJ/article/view/20. 
Prastuti, E. D., Mardiyana, M., \& Pambudi, D. (2019). Penerapan Model Brain Based Learning (BBL) pada Pembelajaran Matematika untuk Meningkatkan Ketuntasan dan Aktivitas Belajar Siswa. SOLUSI: Jurnal Pendidikan Matematika Dan Matematika, 3(1), 10-18. https://doi.org/10.20961/jpmm solusi.v3i1.37675.

Saleh, S., \& Mazlan, A. (2019). The Effects of Brain-Based Teaching with I-Think Maps and Brain Gym Approach Towards Physics Understanding. Jurnal Pendidikan IPA Indonesia, 8(1), 12-21. https://doi.org/10.15294/jpii.v8i1.16022.

Salem, A. S. M. (2017). Engaging ESP Students with Brain-Based Learning for Improved Listening Skills, Vocabulary Re-tention and Motivation. English Language Teaching, 10(12), 182-195. https://eric.ed.gov/?id=EJ1160987.

Sprenger, M. (2011). Cara Mengajar Agar Siswa Tetap Ingat. Erlangga.

Trilipi, D., Subali, B., Anwar, Y., \& Santoso, L. M. (2019). Note-Taking Roundhouse Diagram Strategy: Improving Student Retention On Body Defense System Concepts. Biosfer: Jurnal Tadris Biologi, 12(2), 157-169. https://doi.org/10.21009/biosferjpb.v12n2.157169.

Widiana, I. W., Bayu, G. W., \& Jayanta, I. N. L. (2017). Pembelajaran Berbasis Otak (Brain Based Learning), Gaya Kognitif Kemampuan Berpikir Kreatif Dan Hasil Belajar Mahasiswa. Jurnal Pendidikan Indonesia, 6(1), 1-15. https://doi.org/10.23887/jpiundiksha.v6i1.856.

Wijayanti, T., Prayitno, B., \& Marjono, M. (2013). Pengaruh Pendekatan Savi Melalui Model Pembelajaran Kooperatif Tipe Stad Terhadap Hasil Belajar Pada Siswa Kelas VII SMP Negeri 14 Surakarta. Jurnal Pendidikan Biologi Universitas Sebelas Maret, 5(1). https://jurnal.fkip.uns.ac.id/index.php/bio/article/view/1433.

Woolfolk, A. (2010). Educational Psychology. Pearson Education Inc. 